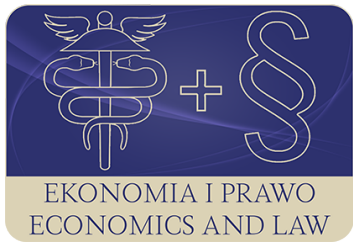

EKONOMIA I PRAWO. ECONOMICS AND LAW

Volume 17, Issue 2, June 2018

$\mathrm{p}$

p-ISSN 1898-2255, e-ISSN 2392-1625

www.economicsandlaw.pl

received 13.06.2017; revised 24.03.2018; accepted 30.06.2018

Citation: Sitek, M. (2018). The risk involved in implementation of innovations in the real estate market. Ekonomia i Prawo. Ecomomics and Law, 17(2): 223-232.

doi:10.12775/EiP.2018.016.

\title{
The risk involved in implementation of innovations in the real estate market
}

\author{
MARCIN SITEK \\ Czestochowa University of Technology, Faculty of Management, Department of Economics, \\ Investment and Real Estate, ul. Dąbrowskiego 69, 42-291 Czestochowa, Poland \\ ๑ sitek_m@poczta.onet.pl
}

\begin{abstract}
Motivation: Innovativeness is considered in the literature as a key success driver that determines competitive advantage of enterprises in the market. However, this activity involves a substantial risk, which is often viewed as one of its major barriers. Nowadays, risk as an element inherent in any business activity is of key importance to enterprises that operate in market conditions and represent the problem that has not been taken into consideration very often. This was the motivation for the analysis of this problem. Moreover, motivation is a widespread aversion to risk among the participants of the real estate market, which, similarly to the necessity to incur substantial expenditures and the uncertainty of the final results connected with the implementation of innovations in the real estate market, represents one of the major barriers to adopt the risk.

Aim: The aim of this study is to present risk factors in investment innovative operations in the real estate market. The study proposed the thesis that a specific level of development of the real estate market corresponds to a certain level of the market risk.

Results: Based on the questionnaire survey of a local market in the context of feedback concerning the national market and the benefits of innovations and the involved risks,

a brief outline of innovative activities in the real estate market was presented, with the involved risk and risk characterization. It was shown that a particularly large share of the risk of innovation activity on the real estate market is at risk for the market, which so far is not very sensitive in Poland and has a high degree of fluctuation of the operating conditions.
\end{abstract}

Keywords: risk; innovative activities; real estate market

JEL: E32; E44; F63 


\section{Introduction}

In the contemporary economy, innovative activity represents a prerequisite for improved competitiveness of enterprises and effective meeting the needs of recipients of products and services. Therefore, based on the literature (Hult et al., 2004, pp. 429-437; Jin et al., 2004, pp. 255-264), innovativeness can be considered as a key success driver that determines competitive advantage of enterprises in the market.

One of the characteristic features of innovative activities, which represent one of its major barriers in enterprises, is uncertainty of the final outcomes and necessity to incur considerable expenditures (Świtalski, 2005) and relatively high risk level (Jonek-Kowalska, 2011, pp. 5-25), which is often viewed as one of its basic barriers. A high level of the innovative risk is generated by substantial expenditure on research and development and high degree of failure involved in implementation.

The aim of this study is to present risk factors in investment innovative operations in the real estate market.

Problems of the risk involved in implementation of innovations, especially in the real estate market, are not reflected by the literature and remain to be relatively unrecognizable.

Innovations and risk as an element inherent in any business activity is of key importance to enterprises that operate in market conditions and represent the problem that has not been taken into consideration very often. This was the motivation for the analysis of this problem.

Moreover, motivation is a widespread aversion to risk among the participants of the real estate market, which, similarly to the necessity to incur substantial expenditures and uncertainty of the final results connected with the implementation of innovations in the real estate market, represents one of the major barriers to adopt the risk.

The study proposed the thesis that a specific level of development of the real estate market corresponds to a certain level of the market risk.

As a result of the processes of intensive globalization of the economy regarded, accelerated economic growth, the main barrier and key problem is evaluation of the risk of innovative activity in the whole economy.

\section{Literature review}

The increase in the importance of innovations in the economic processes is also noticeable in the contemporary real estate market, which substantially utilizes innovative solutions used by both entities and parties of transactions in this sector. Depending on the activities conducted by businesses in the real estate market, the groups of innovations according to the criteria presented by Prystrom (2012) are as follows: 
- technical and technological - they concern modern solutions used in the construction activities, starting from the stage of design and project execution through to the measuring of the building and its use (Komisja Europejska, 2014; Peres et al., 2010, pp. 91-106; Pujari, 2006);

- process (Jaikumar, 1986, pp. 60-76) and organizational (Lee et al., 2012; Pivo \& Fisher, 2010) - they are connected with implementation of technological innovations, legal changes and their adjustment to the needs and requirements of the contemporary customers in the real estate market;

- marketing - they concern the sales and distribution of products and services in the real estate market and involve networking and new methods of presentation of real estate offers;

- financial - they allow entities in the real estate market to start investments through application of modern financial instruments based on the real estate market (derivatives, covered bonds, reverse mortgage, energy efficient mortgage, bancassurance, and new insurance products, dedicated to specific entities in the real estate market).

Especially in Poland, innovative solutions in the real estate market include insurance solutions. Very dynamic innovative tendencies are also observed in the real estate brokering (drones, home stagers, interior photographers and graphic designers, new technologies as cloud computing, Internet of Things and Internet of Everything),

One of the tools for the innovative policy, i.e. tools for implementation of the economic policy are clusters, that will help Europe return to the growth path.

The risk of innovative activities connected with implementation of innovations (Damodaran, 2009) is defined as a likelihood of threats and effects. Therefore, making investment decisions is based on the relationship between the risk and rate of return.

Therefore, risk identification consists in awareness of the events that can have a negative effect on the investment project i.e. determination of the potential sources of risk. Pomykalski (2001) listed the following risk sources that are critical to innovative activities:

- micro level, i.e. the risk resulting from the enterprise;

- intermediate level as market risk;

- macro level, as a risk resulting from the macroeconomic and global determinants.

Classification of the sources of risk in terms of the consequences for the innovative process risk turned out to be important. Keizer et al. (2002) developed a list that classified risk determinants in the innovative processes, grouping them into 12 groups as a risk concerning product technology, production, sources of supplies, supply chain, competition, acceptance of consumers, trade agents and social acceptance, project management and organization, in terms of intellectual property, price control, product positioning and brand positioning. The sources of risks were discussed for each group as a list of conditions that have 
to be met to reduce risks of innovative processes. Detailed analysis of the classification of risk sources points clearly to the fact that the most important component of the analysis of innovation risk is not to start innovative activity but awareness that giving up the activity in the longer perspective can lead to lost competitiveness in the enterprise.

\section{Methods}

The data used to achieve the study aim and support the adopted thesis were derived in 2016 from the results of the survey conducted among the entities operating in the Częstochowa local real estate market. The survey was aimed at developers operating in this market. In total, 16 enterprises responded, with the study sample of 50 people. The enterprises studied were all small and medium-sized enterprises according to the classification of the Central Statistical Office of Poland, operating in the market for ca. 10 to 15 years, with their area of activity focused on the local real estate market of the city of Częstochowa, Poland. The respondents expressed their opinions about innovative activities in their own enterprises and evaluated risks involved in innovativeness.

The enterprises present in the local market of real estate were adopted as entities that operate in this market as they are simultaneously investors, executors and agents. Therefore, it was impossible to determine the structure of the research sample. However, with the specific nature of the local market, the data obtained and the survey can be considered representative. Furthermore, the random selection method was used for the target population as the questionnaire surveys were divided so that all members of the target population had equal chances at simple random sampling (probability sampling).

Availability of information about real estate is of key importance during risk analysis and the choice of the strategy to limit a specific risk. Although all identifiable databases do not meet the condition of completeness of information needed for market examination, the study used also secondary (existing) information regarding real estate market, using the method of analysis of these data.

The study used the results of the survey ordered by PARP (2013). The survey was conducted among 100 enterprises, with the majority of micro- and small enterprises. Nearly half of them were limited liability companies (46\%) and a third were natural persons doing business as sole proprietors.

Part of the data were derived from the survey conducted within the Project Support for monitoring of the cohesion policy of 2007-2013 and 2014-2020 (GUS, 2007-2013). The survey was conducted in a group of microenterprises (with the number of employees below 10 people), with the territorial range of all the Polish voivodships (OECD \& Eurostat, 2008).

Furthermore, the conclusions concerning key actions to ensure further effective development of the Polish economy and their new directions were developed based on the results of the survey conducted by Bogdan et al. (2015) dedicated to leaders of the biggest enterprises in Poland. The study used sec- 
ondary information concerning the real estate market using the method of data analysis.

The methodology adopted in the study allows for presentation of innovative solutions and evaluation of the risk of innovation implementation in the real estate market. Furthermore, the analysis of the research and secondary information allowed for the achievement of the study aim and supporting the proposed thesis.

\section{Risk of innovation implementation to the real estate market}

Innovations are expected to produce demanded changes. However, implementation of new solutions involves high costs which are often difficult to cope with for enterprises. Furthermore, the risk of failure is also difficult in the case of implementation of innovations. Therefore, not all entrepreneurs decide to implement innovative solutions.

In the questionnaire survey conducted in 2016 in the local market, the respondents were asked about innovative activities in their enterprises, evaluation of risk during implementation of innovations from the standpoint of the local market.

In the group of questions concerning innovations, the respondents were asked in particular about motivations and types of innovations, support for innovative activity, types of barriers, risk, its identification and evaluation of future activities. Furthermore, the second group of questions concerned the risk, its measurement, evaluation of its activity and prospects for the future.

The findings demonstrated that $68 \%$ of the respondents declared implementation of innovations in their business activity, with the enterprises focusing on technical and technological innovations followed by marketing innovations (36\%). The motivations indicated by the respondents include pressure of the competitors $(44 \%)$, increased share in the market (32\%), whereas reduction in the harmful effect on the environment was found only in $18 \%$ of the answers.

Respondents emphasized the reduction in risk related to innovations due to collaboration with other entities. Furthermore, while assessing the risk of innovative activities as medium-level, the respondents emphasized that this risk (28\%) is a very important factor that limits this activity. The barriers for implementation of innovations perceived by entrepreneurs in the local market as a risk involved in innovation implementation, include strong competition, lack of financial and human resources and poor distribution channels. When assessing the future activities of the enterprise, $56 \%$ of the respondents claimed that they maintained a medium level of innovations in order to minimize the risk of bankruptcy. Table 1 presents the examples of benefits of innovations and the risks involved in their implementation. As can be seen, these data contain information about the effect of risk factors connected with innovations on the real estate market. 
The last group of questions about innovation sustainable building in the local market in Częstochowa concerned the benefits of implementation of sustainable building in the market and perception of its profitability. The respondents, asked about the benefits concerning sustainable/green buildings, answered that the operating costs, i.e. energy and water, are lower than in the conventional building (54\%) and that sustainable buildings show tendencies for reducing the maintenance costs in long-term use (40\%). Furthermore, 53\% of the participants of the local market, most likely due to its size and level of development in this market, did not have any opinion about cost reduction. Some 43\% of the respondents pointed to a noticeable benefit: the lack of impact on the natural environment (pollution), with only $20 \%$ claiming that the certified buildings have higher rate of return on investments (Jalaei \& Irade, 2015, pp. 95-107).

With regard to the evaluation of the risk of innovation activity, the respondents claimed that the risk is not measured by them. $64 \%$ of the respondents found that they did not measure risk using dedicated tools such as statistical measures (e.g. standard deviation, variance or covariance). Risk measurement used in these enterprises is intuitive or it results from experience and knowledge of the local market or the lack of adequate knowledge and skills. The risk involved in innovation was evaluated by the respondents as medium. However, they realized that abandoning of innovation activities has to lead to deteriorated competitiveness in both local and global markets (Sitek, 2017).

The results of the questionnaire survey of 100 enterprises, with two thirds represented by micro- and small enterprises, ordered by PARP in 2013, concerning the self-rated degree of innovativeness if the activity reveal a relatively high level of innovativeness. $43 \%$ of indications concerned innovation at the level of a market or a country, whereas $21 \%$ - at the international level.

The analysis of the results of the surveys in the Project Support for monitoring of the cohesion policy of 2007-2013 and 2014-2020 (GUS, 2007-2013) concerned microenterprises and, more specifically, indices of innovative activities. The following observations were made for the microenterprises:

- the advantage of construction innovations (technical, technological and process innovations) over innovations connected with the services to the real estate market;

- advantage of the construction sector in the share of revenues on sales of real estate;

- public support for innovative activities is more effective in the construction sector compared to the activities connected with services for the real estate market.

The survey by McKinsey conducted among business leaders, including developers, concerning the key activities to ensure effective development of Polish economy demonstrated that one of the key tasks is investments in business innovativeness.

The most recent report of the European Innovation Scoreboard 2016 (European Commission, 2017) also demonstrated an increase in innovativeness in- 
dex. Compared to the results obtained in 2015, Poland progressed by one place to the 23rd position.

Analysis of the examinations shows that implementation of product, process and organizational innovativeness was indicated by $20 \%$ of microenterprises, whereas marketing innovations connected with services in the real estate market — by ca. $10 \%$.

The marketing risk and its analysis represent the synthetic process of measurement and evaluation of the events in the business environment. Information about the risk and marketing opportunities reveal threats and opportunities of the enterprises and are necessary for precise evaluation of the economic and financial results of the enterprises

The most important risk factors in innovative activities include the risk concerning product and brand positioning, market life cycle, its acceptance by consumers, risk in terms of competition, control and prices i.e. acceptance of new product. However, the most important risk in innovative activities is market risk since technical, technological and organizational successes of innovative activity are connected with the innovative success of the product in the market.

\section{Conclusion}

The aim of the paper was to present the risk factors in innovative activities in the real estate market and to evaluate their impact on this market. The study proposed the hypothesis that a specific level of development in the real estate market corresponds to a certain level of investment risk.

The study presented a brief overview of innovative activities, with particular focus on innovations in the real estate market. Analysis of the innovative activity and risk involved with this activity was based on the results of the survey concerning the local real estate market in micro- and small enterprises,

The study demonstrated that:

- with respect to the innovative activity in the sector of real estate, the innovative services dominate substantially over the investment activities in the construction sector, thus representing the value added;

- in the services in the real estate market, innovations concern in particular marketing, with marketing surveys concerning meeting the customer needs as one of the aspects of combating competition;

- analysis of the barriers of perception of innovations by enterprises in Po land demonstrated low demand for innovative products and services as the major barrier;

- noticeable differences in perception and using the programs of public and private support were not found among investors in the real estate market. In both cases, the key problem of using them indicated by stake holders was administrative problems in finding the resources. The value added in this case is the necessity to remove this barrier; 
- the most important component of the analysis of innovation risk is not to start innovative activity but the awareness that giving up the activity in the longer perspective can lead to the deterioration of the competitiveness.

In conclusion, the risk of the market, which is little transparent and characterized by large variability of conditions, has a substantial effect on the level of risk of innovative activities in the real estate market.

\section{References}

Bogdan, W. Boniecki, D., Labaye, E., Marciniak, T., Nowacki, M. (2015). Polska 2025. Nowy motor wzrostu w Europie. Retrieved 02.02.2016 from http:// mckinsey.pl.

Damodaran, A. (2009). Ryzyko strategiczne. Warszawa: Wydawnictwo Akademickie i Profesjonalne Press.

European Commission. (2017). European Innovation Scoreboard. Retrieved 02.01.2017 from http://ec.europa.eu.

Filo, Ł. (2011). Rola badań marketingowych $w$ przedsiębiorstwie. Retrieved 02.10.2016 from http://www.inwestycjewinnowacje.pl.

GUS. (2007-2013). Raport końcowy. Badanie innowacji w mikroprzedsiębiorstwach. Retrieved 05.02.2017 from http://stat.gov.pl.

Hult, G.T.M., Hurley, R.F., \& Knight, G.A. (2004). Innovativeness: its antecedents and impact on business performance. Industrial Marketing Management, 33(5). doi:10.1016/j.indmarman.2003.08.015.

Jaikumar, R. (1986). Post-industrial manufacturing. Harvard Business Review, November.

Jalaei, F., \& Irade, A. (2015). Integrating building information modelling (BIM) and LEED system at the conceptual design stage of sustainable building. Sustainable Cities and Society, 18. doi:10.1016/j.scs.2015.06.007.

Jin, Z., Hewitt-Dundas, N., \& Thompson, N.J. (2004). Innovativeness and performance: evidence from manufacturing sectors. Journal of Strategic Marketing, 12(4). doi:10.1080/0965254042000308075.

Jonek-Kowalska, I. (2011). Źródła ryzyka w procesie wprowadzania innowacji technologicznych. Zarządzanie i Edukacja, 80.

Keizer, J., Halman, J., \& Song, M. (2002). From experience: applying the risk diagnosing methodology. Journal of Product Innovation Management, 19(3). doi:10.1016/S0737-6782(02)00138-8.

Komisja Europejska. (2014). HORIZON 2020, Program ramowy UE $w$ zakresie badań naukowych i innowacji. Retrieved 02.01.2017 from https://ec.europa.eu.

Lee, S.M., Olson, D.L. \& Trimi, S. (2012). Co-innovation: convergenomics, collaboration, and co-creation for organizational values. Management Decision, 50(5). doi:10.1108/00251741211227528.

OECD, \& Eurostat. (2008). Podręcznik Oslo: Zasady gromadzenia i interpretacji danych dotyczących innowacyjności. Retrieved 12.10.2015 from http://www. uwm.edu.pl. 
PARP. (2013). Ocena zapotrzebowania przedsiębiorstw na wsparcie działalności badawczo-rozwojowej. Retrieved 07.12.2016 from https://badania.parp.gov.pl.

Peres, R., Muller, E., \& Nahajan, V. (2010). Innovation diffusion and new product models: A critical review and research directions. International Journal of Research in Marketing, 27 (2). doi:10.1016/j.ijresmar.2009.12.012.

Pivo, G., \& Fisher, J.D. (2010). Income, value and returns in socially responsible office properties. Journal of Real Estate Research, 32(3).

Pomykalski, A. (2001). Zarządzanie innowacjami. Warszawa-Łódź: PWN.

Prystrom, J. (2012). Innowacje w procesie rozwoju gospodarczego. Istota i uwarunkowania. Warszawa: Difin.

Pujari, D. (2006). Eco-innovation and new product development: understanding the influences on market performance. Technovation, 26(1). doi:10.1016/j. technovation.2004.07.006.

Sitek, M. (2017). Assessment of sustainable building by the participants of the local real estate market in Czestochowa. European Journal of Sustainable Development, 6(4).

Świtalski, W. (2005). Innowacje i konkurencyjność. Warszawa: Wydawnictwo Uniwersytetu Warszawskiego.

\section{Acknowledgements}

Author contributions: author has given an approval to the final version of the article.

Funding: this research was undertaken as part of the Contemporary determinants of organization management project and was fully funded by a grant (BS/PB-603/3010/2014).

Note: the results of this study were presented at 9th International Conference on Applied Economics Contemporary Issues in Economy (June 22-23, Toruń, Poland). 


\section{Appendix}

\section{Table 1.}

Examples of benefits and risk of innovation in the real estate market

\begin{tabular}{|c|c|}
\hline Benefits of innovation & Risks \\
\hline meeting customer needs & lack of acceptance of a product in the market \\
\hline increased profit & $\begin{array}{c}\text { innovation involves high investments which does not necessarily have to be } \\
\text { returned during the entire product life cycle }\end{array}$ \\
\hline increased market share & $\begin{array}{l}\text { too high concentration of resources and comments on new products at } \\
\text { the expense of quality and marketing of the current product }\end{array}$ \\
\hline the use of new market opportunities & enterprise dependence on new products \\
\hline strategic position hedging & lack of resources for introduction of the product \\
\hline increased competitive advantage & $\begin{array}{l}\text { taking over the enterprise by partners during realization of the investment } \\
\text { in partnership (know-how transfer risk) }\end{array}$ \\
\hline personal approach to services & lack of reduction of the marketing risk is possible \\
\hline
\end{tabular}

Source: Own preparation based on the analysis of surveys and Filo (2011). 